\title{
INTRACELLULAR ENZYMES AND KININ ENZYMES IN SYNOVIAL FLUID IN JOINT DISEASES* ORIGIN AND RELATION TO DISEASE CATEGORY
}

\author{
BY \\ M. K. JASANI, M. KATORI, AND G. P. LEWIS \\ From CIBA Laboratories, Horsham, Sussex, and the Centre for Rheumatic Diseases, Glasgow
}

In recent years, increasing evidence (see Weissmann, 1967) has been presented by several workers that release of lysosomal hydrolases during cell injury or excessive phagocytosis might be the final common pathway for the mediation of local injury to the joint in various rheumatic diseases.

In the present investigation we have studied changes in the synovial fluid obtained from inflammatory and non-inflammatory joints, not only of lysosomal enzymes, but of five intracellular enzymes selected to represent different intracellular compartments. Although the study has not revealed a characteristic composition of the synovial fluid for any of the diseases studied, it has indicated that, in the rheumatic diseases, the release of lysosomal enzymes is accompanied by the release of other intracellular enzymes. This suggests that the presence of lysosomal enzymes in the synovial fluid is the result of an overall change in cell permeability or of cell death rather than due to any specific change in the lysosomes.

As kinins have been suggested as mediators of some of the pharmacological effects of the acute inflammatory reponse (Lewis, 1964), changes in the kinin-forming and kininase activities and alterations in the kininogen content have been studied in the same samples of synovial fluid. Recently, three independent groups of workers have located a weak kinin-forming activity and a kininase activity in leucocytes (Eisen, 1966; Greenbaum and Kim, 1967; Melmon and Cline, 1967) and have suggested that these polymorphonuclear leucocyte-born enzymes play a major role in the continuation of chronic inflammation.

In the present study we describe several findings which suggest that, contrary to previous reports, the constituents of the kinin system in synovial fluid

\footnotetext{
Correspondence should be addressed to: Dr. G. P. Lewis, Research Division, CIBA Laboratories Limited, Horsham, Sussex.

* Given at a meeting of the Heberden Society at The Kennedy Institute, London, W.6, on February 14, 1969.
}

are mainly derived from plasma and not from the invading leucocytes.

\section{Material and Methods}

A total of 64 patients with unilateral or bilateral knee joint effusion due to one of the five major diseases characterized by polyarthritis was studied (Table I).

TABLE I

RHEUMATIC DISEASES STUDIED

\begin{tabular}{l|c|cc}
\hline \multicolumn{1}{c|}{ Diagnosis } & \multicolumn{2}{|c}{ Sex } \\
& No. of Patients & \multicolumn{2}{|c}{} \\
\cline { 2 - 4 } & & Male & Female \\
\hline "Classical" Rheumatoid & 35 & 9 & 26 \\
Arthritis (RA) & 7 & 6 & 1 \\
"Probable" or "Possible" RA & 10 & 2 & 8 \\
Osteoarthrosis & 8 & 8 & 0 \\
Reiter's Disease & 4 & 0 & 4 \\
Arthritis with Psoriasis & & & \\
\hline
\end{tabular}

Their salient clinical features are summarized below:

"Classical" Rheumatoid Arthritis.-35 (26 female, 9 male) of the 64 patients had "definite" or "classical" RA as defined by the revised American Rheumatism Association criteria (Ropes, Bennett, Cobb, Jacox, and Jessar, 1959). At the time of the study, thirteen of these patients were receiving corticosteroid drugs, and the remaining 22 patients received aspirin in various forms for relief of joint symptoms. The estimated mean prednisolone equivalent dose of corticosteroid drugs was $8 \mathrm{mg}$./day (range 5-15). The amount of aspirin taken ranged from 2.4 to $4.0 \mathrm{~g}$./day; the estimated average dose being about $3 \cdot 2 \mathrm{~g}$./day.

Probable and Possible RA.-Seven patients (6 male, one female) had chronic polyarthritis with knee joint effusion but failed to meet all the criteria of Ropes and others (1959). None gave a positive test for rheumatoid factor in the serum or synovial fluid as judged by the haemagglutination test (Heller, Jacobson, and Kolodny, 1949), or by the Hyland latex (FII) slide test. Furthermore, a detailed radiological examination of all joints failed to reveal the presence of articular erosions in many of them. They are therefore referred to as having "probable" or "possible" RA. There were no corticosteroid-treated patients in this group. 
Osteoarthrosis.-A further group of ten patients (two male, 8 female), had osteoarthrosis of knee joints with normal erythrocyte sedimentation rate (ESR), negative tests for rheumatoid factor in serum and synovial fluid, and radiological changes principally characterized by osteophyte formation and lipping of marginal bone. The majority of those in this group took little in way of analgesics.

Reiter's Disease.-Eight patients (all male) had polyarthritis of acute onset following upon or in association with mucocutaneous ulceration, conjunctivitis, and non-gonoccocal urethro-prostatitis. The minimum duration of polyarthritis in the group was 4 weeks (range 4 to 12). All had spontaneous remission of the arthritis, except one patient in whom the knee joint involvement persisted for a period of 10 years, and who experienced periodical exacerbations with development of massive knee joint effusions. Apart from this one man, all in this group had negative tests for rheumatoid factor in the serum and synovial fluid and demonstrated no erosive articular changes. These patients fulfilled the criteria for the diagnosis of Reiter's disease, and henceforth are referred to as such. There were no corticosteroid-treated patients in this group.

Polyarthritis with Psoriasis.-Four patients (all female) had polyarthritis associated with a moderate to severe degree of psoriasis. Their joint disease was of long duration (range 5 to 30 years); it was controlled with aspirin in two patients, and with corticosteroid drugs in the other two. A weak positive test for rheumatoid factor (titre 1:32) was obtained in the serum of one patient, and in the synovial fluid in another. The antinuclear factor test, as performed by the method of Beck (1961), was positive (titre $1: 16$ ) in serum of one patient (RF test negative), but was negative in all synovial fluids. Two patients demonstrated radiological changes typical of psoriasis in the distal interphalangeal joints of both hands.

\section{Collection and Analysis of Samples}

Synovial fluid was obtained from the above patients by aspiration of the knee under strict aseptic conditions. A 20-ml. sample of venous blood was taken after the knee aspiration and before the patient returned to the ward.

Heparinized synovial fluid and plasma samples were stored at $-20^{\circ} \mathrm{C}$. until the biochemical and pharmacological examination.

Fresh synovial fluid was diluted with normal saline to obtain the leucocyte counts, and smears were stained to observe cell morphology.

For studies on the distribution of proteins and enzymes between cells and supernatant, fresh synovial fluid was centrifuged at approximately 4,500 r.p.m. for 10 minutes. The supernate was measured, and after several washes, the cell pellet was resuspended in an equivalent amount of saline. Both were then stored at $-20^{\circ}$ C. until analysis.

\section{BIOCHEMICAL DETERMINATIONS}

Protein was determined by the method of Lowry, Rosebrough, Farr, and Randall (1951); acid phosphatase (acid phos.) activity was assayed using the method of Harrison (1957); $\beta$-glucuronidase ( $\beta$-gluc.) by the method of Fishman (1963); the standard biochemical test combinations (Blehringer and Sohne, GMBH) were employed to determine lactic dehydrogenase (LDH) activity; glutamic-oxalacetic transaminase (GOT) was assayed using BDH enzyme set 2 (based on the method of Karmen, Wróblewski, and LaDue, 1955); glutamic-pyruvic transaminase (GPT) with BDH enzyme assay set 3 (which employs the method of Wróblewski and LaDue, 1956). Potassium was determined using an E.I.L. flame photometer.

\section{PHARMACOLOGICAL TECHNIQUES}

Smooth Muscle Stimulating Substances.-The action of the samples was studied on the isolated guinea-pig ileum suspended in Tyrode's solution at $37^{\circ} \mathrm{C}$. and the isolated rat uterus suspended in Munsick's solution at $28^{\circ} \mathrm{C}$. Contact between synovial fluid and glass was carefully avoided at all times. The samples were incubated and transferred to the organ bath in polythene tubing.

\section{The Kinin System}

Kinin-forming activity, kininase activity, and kininogen content were determined on the basis of the following relationships:

Preactive kinin-forming
enzyme $\quad \begin{array}{r}\text { Acidification } \\ \begin{array}{c}\text { dilution, } \\ \text { activators, } \\ \text { etc. } \\ \text { Kinin-forming }\end{array}\end{array} \rightarrow \begin{array}{r}\text { Kinin-forming } \\ \text { enzyme }\end{array}$

Kinin-Forming Activity.-In order to estimate kininforming activity in synovial fluid and plasma, different methods were employed to activate all the kinin-forming enzymes. The experiment illustrated in Fig. 1 shows some examples. Dilution 1:4 in phosphate buffer produced a small formation; addition of purified kininogen to the diluted synovial fluid produced only a small formation; addition of kininase inhibitor and kininogen increased formation but the formed kinins were inactivated after $40 \mathrm{~min}$. incubation. Acidification (Frey, Kraut, and Werle, 1950; Elliott and Lewis, 1965) produced a good formation and the formed kinins remained because acidification destroyed most of the kininase activity; addition of kininogen increased formation even 
more. Acid activation of kinin-forming enzymes was therefore adopted with addition of kininase inhibitor O-phenanthroline (Amundsen and Nustad, 1964) to ensure inhibition of any kininase remaining after acidification.

Excess substrate in the form of purified human kininogen was added to each assay to obtain maximum kinin-forming activity.

Procedure: Synovial fluid or plasma 0.3 or $0.5 \mathrm{ml}$. was acidified to $\mathrm{pH} 2$ by addition of $\mathrm{N} \mathrm{HCl}$, and after 10 or $20 \mathrm{~min}$. at $37^{\circ} \mathrm{C}$. was neutralized with $\mathrm{N} \mathrm{NaOH}$. Some samples were acidified immediately after collection and remained at $\mathrm{pH} 2$ until tested. The mixture was incubated in $0.1 \mathrm{M}$ phosphate buffer at $\mathrm{pH} 7.4$ with purified kininogen $(0.5-1.0 \mathrm{mg}$.) in the presence of kininase inhibitor phenanthroline $\left(10^{-4} \mathrm{M}\right)$. The total volume of the mixture was $2 \mathrm{ml}$. and at various time intervals aliquots of between 0.05 and $0.2 \mathrm{ml}$. were taken and assayed on the isolated rat uterus against a standard of synthetic bradykinin.

In some experiments the kinin-forming enzymes were activated by dilution with Tyrode solution or by glass contact. In the contact activation experiments the sample was incubated with glass ballotini $(1 \mathrm{~g} . / \mathrm{ml}$.$) ,$ O-phenanthroline $10^{-4} \mathrm{~g}$. $/ \mathrm{ml}$., and kininogen. Maximum formation occurred after 10 to $20 \mathrm{~min}$.

Kininogen Content.-The method of Diniz and Carvalho (1963) was employed. Kinin-forming and kininase activity were destroyed by boiling with acetic acid. The substrate so denatured by this procedure formed kinin when reacted with trypsin.

Procedure: $0.2 \mathrm{ml}$. synovial fluid or plasma were boiled in $1.8 \mathrm{ml}$. of 0.2 per cent. acetic acid for $30 \mathrm{~min}$. and neutralized with $\mathrm{N} \mathrm{NaOH}$. The mixture was then incubated with $200 \mu \mathrm{g}$. trypsin dissolved in saline and $0.5 \mathrm{ml} .0 .2 \mathrm{M}$ tris buffer at pH 7.8 for $30 \mathrm{~min}$. at $37^{\circ} \mathrm{C}$. The reaction was terminated by boiling for $10 \mathrm{~min}$. The kinin so formed was assayed against a standard of synthetic bradykinin on the isolated rat uterus.

Kininase Activity.-After addition of soya bean trypsin inhibitor to prevent any formation of kinin, the sample was incubated with bradykinin and the rate of inactivation followed. Sufficient bradykinin was added to make the amount of kinin already present negligible.

Procedure: Synovial fluid or plasma 0.3 or $0.5 \mathrm{ml}$. was incubated in phosphate buffer at $\mathrm{pH} 7 \cdot 4$ with synthetic bradykinin $(500 \mathrm{ng} . / \mathrm{ml}$. final concentration) in the presence of soya bean trypsin inhibitor $10^{-4} \mathrm{~g}$. $/ \mathrm{ml}$. The total volume of the mixture was $2 \mathrm{ml}$. and an aliquot of $0.05 \mathrm{ml}$. was taken every $5 \mathrm{~min}$. and assayed on the isolated rat uterus against a standard of synthetic bradykinin.

Kinins.-Kinins were assayed by direct application of fluids to the isolated rat uterus in the presence of atropine D
$10^{-7} \mathrm{~g} . / \mathrm{ml}$., mepyramine $10^{-7} \mathrm{~g} . / \mathrm{ml}$., or BOL $10^{-6} \mathrm{~g} . / \mathrm{ml}$., or $10^{-7} \mathrm{~g} . / \mathrm{ml}$. In addition, some samples were incubated with chymotrypsin to confirm the peptide nature of the substance.

To prevent destruction of kinin which might be present, some samples were added to boiling ethanol immediately after collection and boiled for $\mathbf{1 0}$ minutes. After evaporation of the ethanol, the dried residue was dissolved in a volume of saline equal to that of the original sample before assay.

Preparation of Purified Kininogen.-Kininogen was purified from freshly collected human plasma according to the method of Brocklehurst and Mawer (1966). Before use, this powder was dissolved in distilled water to a concentration of $1 \mathrm{mg}$. protein $/ \mathrm{ml}$. Incubation of $0.5 \mathrm{ml}$. of this kininogen for $30 \mathrm{~min}$. with trypsin 200 $\mu \mathrm{g} . / \mathrm{ml}$. in $0.1 \mathrm{M}$ phosphate buffer $\mathrm{pH} 7.4$ (total volume $2 \mathrm{ml}$.) produced $300-400 \mathrm{ng}$. bradykinin/mg. of protein. Incubation of the kininogen in phosphate buffer without the trypsin failed to form kinin. Incubation of the kininogen with synthetic bradykinin in phosphate buffer caused no destruction of the bradykinin. In some preparations, free kinins were detected but in such small amounts (less than $1 \mathrm{ng} . / \mathrm{ml}$.) that they did not interfere with the assays.

\section{Results}

\section{Pharmacological Activity}

SMOOTH MUSCLE STIMULANTS.-Alcoholic extracts of synovial fluid and plasma caused contraction of the rat uterus. Part of this activity was probably due to the presence of a kinin as its action was not reduced by antagonists of histamine, (mepyramine $10^{-7} \mathrm{~g} . / \mathrm{ml}$.) acetylcholine (atropine $10^{-7} \mathrm{~g} . / \mathrm{ml}$.) and only slightly reduced by the antagonist of 5-hydroxytryptamine, bromolysergic acid diethylamide (BOL $10^{-7} \mathrm{~g} . / \mathrm{ml}$.). Further, its activity was greatly reduced on incubation with chymotrypsin. The amounts of kinin found in samples of synovial fluid were approximately the same as those found in plasma, and varied between 2 and $40 \mathrm{ng} . / \mathrm{ml}$. when expressed as bradykinin. When tested on the isolated rat stomach preparation the extracts caused a contraction which was nearly abolished by BOL $10^{-7} \mathrm{~g} . / \mathrm{ml}$. These findings indicate that the extracts contained 5HT as well as kinins.

KININ-FORMING ACTIVITY.-The quantitative relationship between the different methods of activation are given in Table II (overleaf).

Acidification of synovial fluid and plasma with $\mathrm{N} \mathrm{HCl}$ immediately after collection produced the greatest activation (Fig. 1, overleaf). 
TABLE II

FORMATION OF KININ IN SYNOVIAL FLUID AND PLASMA AFTER DIFFERENT METHODS OF ACTIVATION OF KININ-FORMING ENZYMES

\begin{tabular}{|c|c|c|c|c|c|c|c|c|}
\hline \multirow{2}{*}{$\begin{array}{l}\text { Substance Tested } \\
\text { Synovial Fluid }\end{array}$} & \multicolumn{2}{|c|}{$\begin{array}{l}\text { Dilution } 1: 4 \\
10 \text { min. } \quad \text { Maximum }\end{array}$} & \multicolumn{2}{|c|}{$\begin{array}{l}\text { Glass Contact } \\
10 \text { min. } \\
\text { Maximum }\end{array}$} & \multicolumn{2}{|c|}{$\begin{array}{l}\text { Acidification after Freezing } \\
10 \text { min. }\end{array}$} & \multicolumn{2}{|c|}{$\begin{array}{l}\text { Collection in Acid } \\
10 \text { min. }\end{array}$} \\
\hline & $\begin{array}{l}348 \\
\pm 44(6)\end{array}$ & $\begin{array}{r}377 \\
\pm 40\end{array}$ & $\begin{array}{r}341 \\
\pm 50(7)\end{array}$ & $\begin{array}{r}373 \\
\pm 49\end{array}$ & $\begin{array}{l}184 \\
\pm 17(16)\end{array}$ & $\begin{array}{r}367 \\
\pm 65\end{array}$ & $\begin{array}{l}345 \\
\pm 93(11)\end{array}$ & $\begin{array}{r}752 \\
\pm 205\end{array}$ \\
\hline Plasma & $\begin{array}{r}692 \\
\pm 218(5)\end{array}$ & $\begin{array}{r}880 \\
\pm 363\end{array}$ & $\begin{array}{r}769 \\
\pm 339(5)\end{array}$ & $\begin{array}{l}1,062 \\
\pm 311\end{array}$ & $\begin{array}{l}320 \\
\pm 47(6)\end{array}$ & $\begin{array}{r}733 \\
\pm 232\end{array}$ & $\begin{array}{l}581 \\
\pm 91(11)\end{array}$ & $\begin{array}{l}1,153 \\
\pm 182\end{array}$ \\
\hline
\end{tabular}

Values given in ng. bradykinin formed per ml. synovial fluid or plasma \pm standard error. Number of samples tested given in brackets. Maximum formation is that which occurred within $60 \mathrm{~min}$.

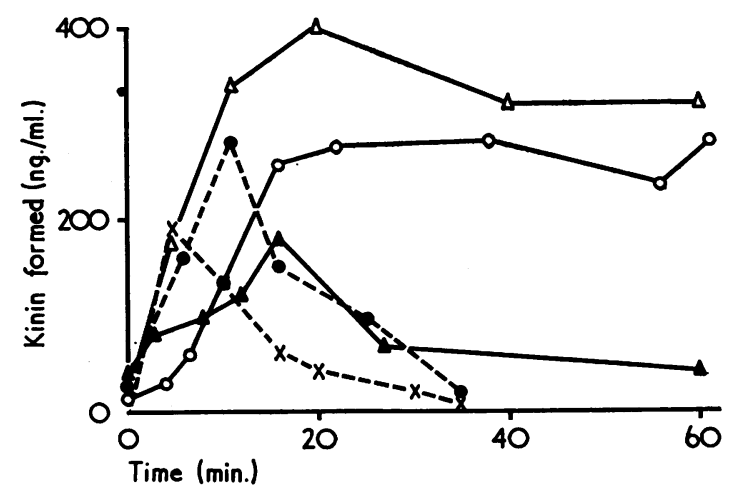

Fig. 1.-Estimation of kinin-forming activity in the same sample of synovial fluid by different methods of activation.

Dilution of synovial fluid $1: 4$ with phosphate buffer at $\mathrm{pH} 7 \cdot 4$ Dilution plus addition of kininogen $0 ; 5 \mathrm{mg} . X-X$;

Dilution plus addition of kininogen $0.5 \mathrm{mg}$. and phenanthroline $10^{-4} \mathrm{M}$

Acidification of synovial fluid to $\mathrm{pH} 2$ with $\mathrm{N} \mathrm{HCl}$ for $10 \mathrm{~min}$. at $38^{\circ}$ C. followed by neutralization with $\mathrm{N} N \mathrm{NaOH} O-\mathrm{O}$;

Acidification plus addition of kininogen $0.5 \mathrm{mg} . \Delta-\Delta$.

All incubations were carried out at $38^{\circ} \mathrm{C}$.

After acid treatment, kinin formation continued after $10 \mathrm{~min}$. considerably more so than when activation (Fig. 1) was brought about by dilution or glass activation. With the latter types of activation, there was little or no increase in kinin content of the incubation mixture after $10 \mathrm{~min}$. in spite of the presence of kininase-inhibitor O-phenanthroline.

The mechanism of acid activation is unknown, but the enzymic formation of kinins in a sample of synovial fluid after acidification according to the conditions described in the methods and subsequent neutralization is illustrated in Fig. 2 (opposite). At $30 \mathrm{sec}$. after neutralization, about $10 \mathrm{ng}$. bradykinin/ $\mathrm{ml}$. incubation mixture had been produced, while after $20 \mathrm{~min}$. or longer the mixture contained more than $100 \mathrm{ng} . / \mathrm{ml}$. Treatment of plasma in the same way produces the same kind of formation. The sensitivity of the isolated smooth muscle remained constant throughout the experiment.

pH Requirements.-It has recently been reported
(Greenbaum and Kim, 1967) that rabbit polymorphonuclear leucocytes contain an enzyme which is capable of forming kinins at $\mathrm{pH} 5$ when incubated with human kininogen. In the present experiments, rheumatoid synovial fluid, which contains many polymorphonuclear leucocytes (vide infra), was acidified (as described under Methods) and instead of neutralizing to $\mathrm{pH} 7.4$ the $\mathrm{pH}$ was brought to $5 \cdot 0$. Incubation now failed to produce kinin formation, as shown in Fig. 2. However, when this acid incubation mixture was subsequently neutralized and incubated at $\mathrm{pH} 7 \cdot 4$, kinin formation commenced.

Inhibitors.-Kinin formation in synovial fluid like that in plasma was inhibited by soya bean trypsin inhibitor $100 \mu \mathrm{g} . / \mathrm{ml}$. Trasylol $350-750 \mathrm{u} . / \mathrm{ml}$., a protease inhibitor extracted from bovine lung, also caused some inhibition of kinin formation in synovial fluid and plasma. Again, this is not in agreement with the findings of Greenbaum and Kim (1967) for the leucocyte kinin-forming enzyme.

KININASE ACTIVITY.-When bradykinin is incubated with synovial fluid or plasma under the conditions described in the methods, the peptide is destroyed within a few minutes. In order to obtain some quantitative measure of the amount of enzyme activity present, the body fluids were diluted with buffer at $\mathrm{pH} 7 \cdot 4$. Under these conditions it was found that the half-life of bradykinin was about the same in synovial fluid as in plasma.

As with kinin-forming activity, the kininase enzyme resembles plasma kininase and is different to that found by Zachariae, Malmquist, and Oates (1966) and Greenbaum and Kim (1967) to be present in polymorphonuclear leucocytes. As shown in Fig. 3 (opposite), the kininase activity in synovial fluid and in plasma is inhibited by EDTA. However, DFP, which inhibits the bradykinin-destroying activity of leucocytes, does not reduce the kininase activity of synovial fluid or plasma. 


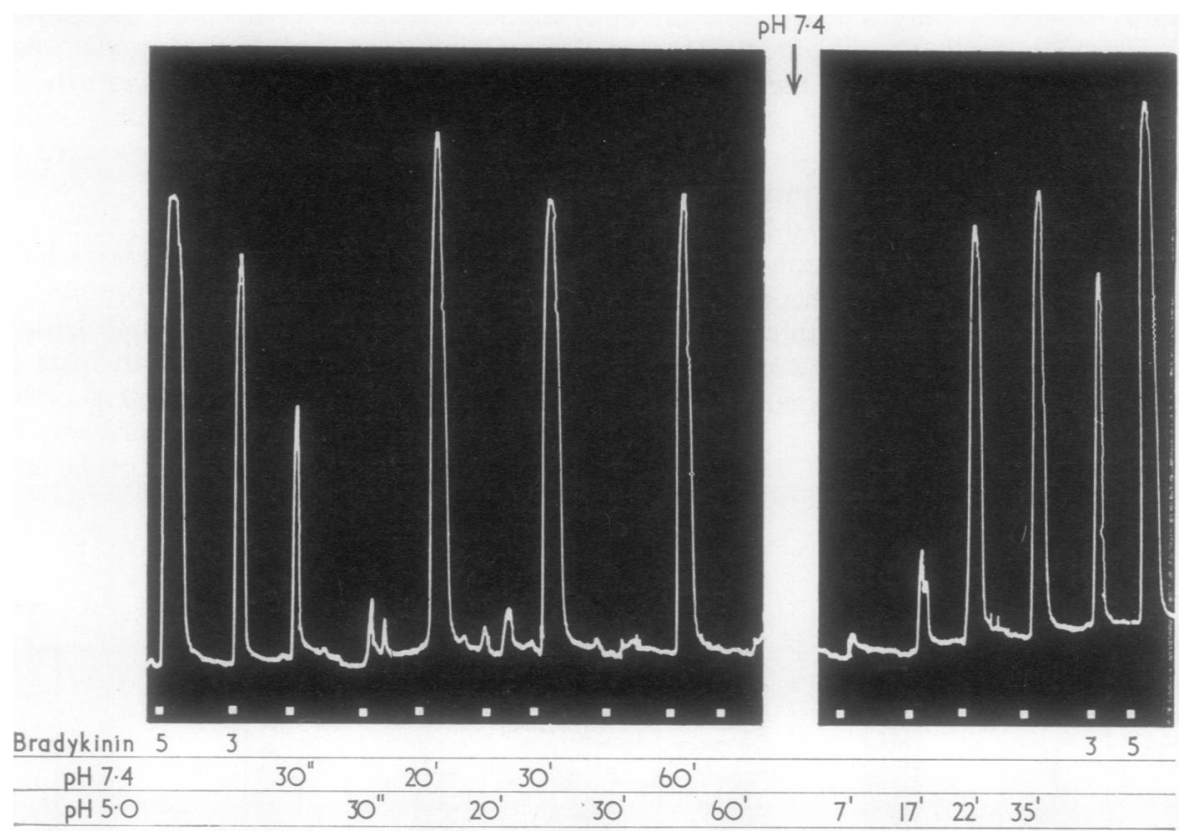

Fig. 2.-Kinin formation in synovial fluid. Responses of the isolated rat uterus to bradykinin (doses in ng./bath) and to aliquots of mixtures containing acid activated non-centrifuged synovial fluid $0.3 \mathrm{ml}$., kininogen $0.6 \mathrm{mg}$., $\mathrm{O}$ phenanthroline $10^{-4} \mathrm{M}$, and either phosphate buffer at $\mathrm{pH} 7.4$ or acetate buffer at $\mathrm{pH} 5 \cdot 0 \mathrm{up}$ to $1 \cdot 2 \mathrm{ml}$. Samples were neutralized before adding to the organ bath. Volumes of aliquots added to the organ bath are given in $\mathrm{ml}$. At the arrow, the mixture at $\mathrm{pH} 5.0$ was neutralized to $\mathrm{pH} 7.4$ with $\mathrm{N} \mathrm{NaOH}$ and phosphate buffer.

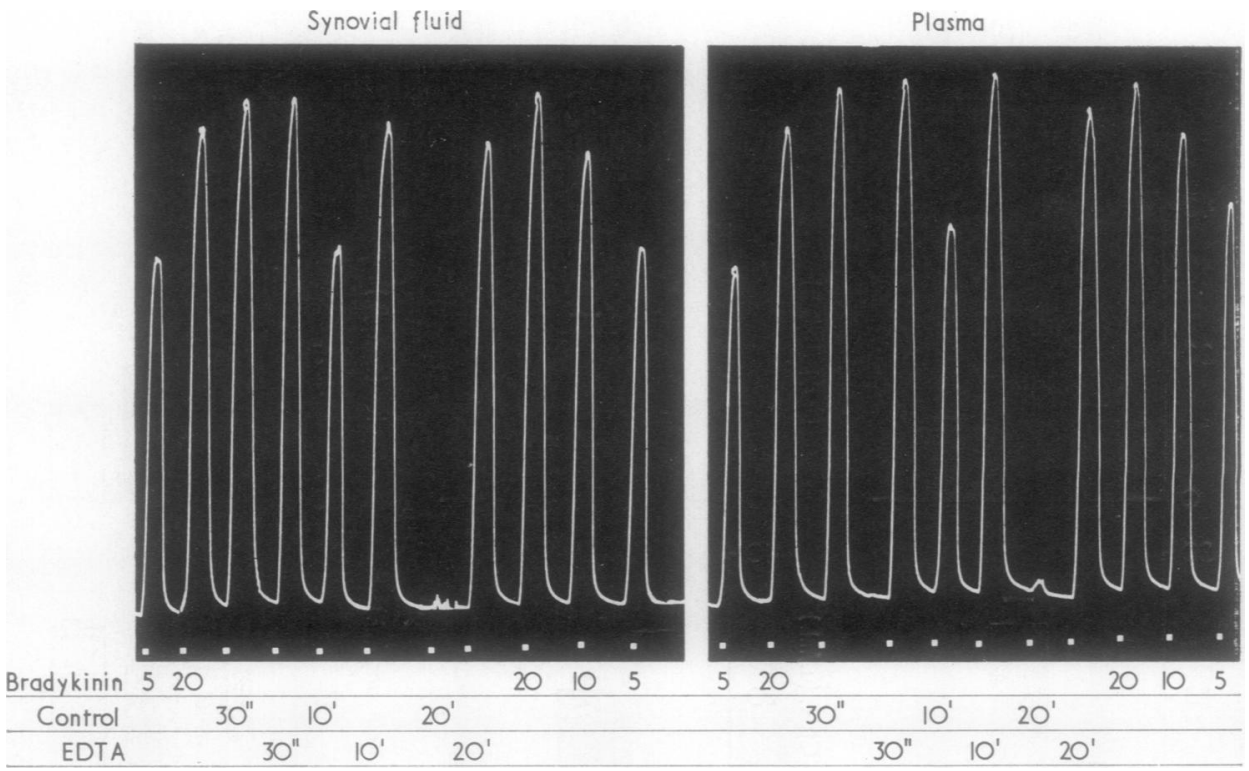

Fig. 3.-Inhibition of kininase activity in synovial fluid and plasma by EDTA. Responses of the rat uterus to bradykinin Fig. 3.- Inen in (doses given in ng./bath) and to $0.05 \mathrm{ml}$. of mixtures containing non-centrifuged synovial fuid $0.3 \mathrm{ml}$. or plasma $2.2 \mathrm{ml}$., bradykinin $1 \mu \mathrm{g}$. ., soya bean trypsin inhibitor $10^{-4} \mathrm{~g} . / \mathrm{ml}$., EDTA $10^{-4} \mathrm{M}$, and phosphate buffer $\mathrm{pH} 7.4 \mathrm{up}$ to $2 \mathrm{ml}$. $\mathrm{Control}$
mixtures in which EDTA was omitted were incubated simultaneously. All incubations were made at $38^{\circ} \mathrm{C}$. The times mixtures in which EDTA was omitted were incubated simultaneously. All incubations were math
at which aliquots were taken and added to the organ bath are given. 
When tested at $\mathrm{pH} 5$, only a small amount of bradykinin-destroying activity remained. It was not significantly different whether the cells were present or not.

KININOGEN CONTENT.-The concentration of kininogen was found to be lower in synovial fluid than in plasma as also was the concentration of protein (Figs 4 and 5). But, although it bore some relationship to the protein concentration when calculated in terms of activity per mg. protein, the kininogen in synovial fluid was lower than in plasma.

ORIGIN OF KININ ENZYMES.-Fig. 4 shows the kinin-forming activity, the kininase activity, and the kininogen content of samples of plasma and cellcontaining and cell-free synovial fluid. These results show no difference between the activities in the cell-free and cell-containing synovial fluid, although the activities in plasma were significantly higher.

These findings strongly suggest that the components of the kinin-system (precursors of kininforming enzymes, kininogen and kininase) in the synovial fluid are mainly derived from plasma and not from the leucocytes and other cells present in the synovial fluid. The inference was furthermore supported by results of analysis of the cell pellet and synovium.
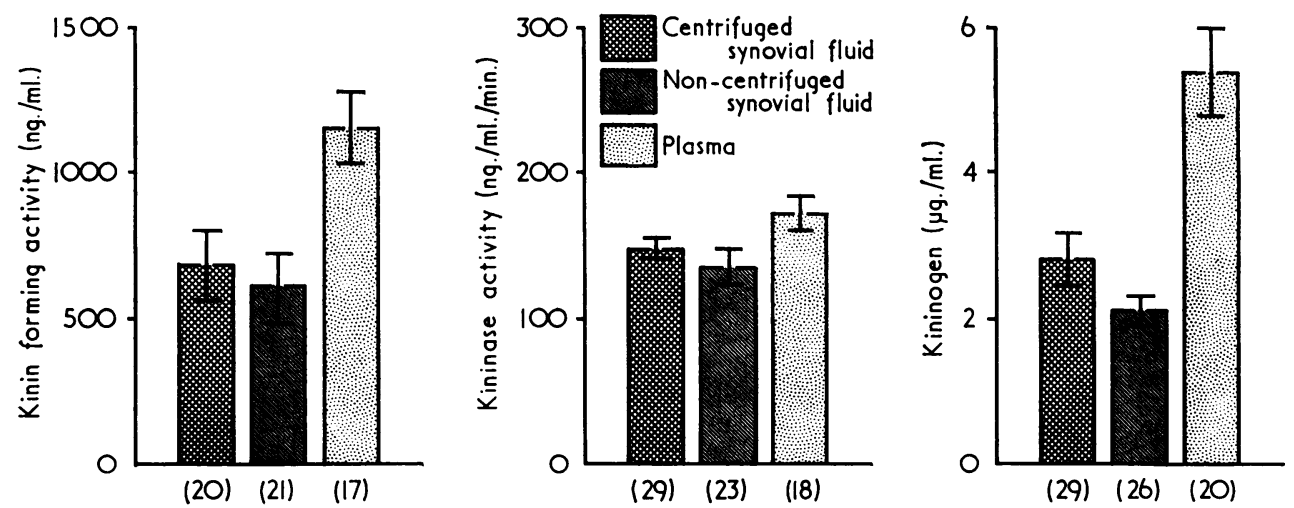

Fig. 4.-Kinin-forming and kininase activity and kininogeni $n$ synovial fluid (with and without centrifugation) and in plasma. Values are the means \pm standard errors. The number of experiments are shown in brackets.
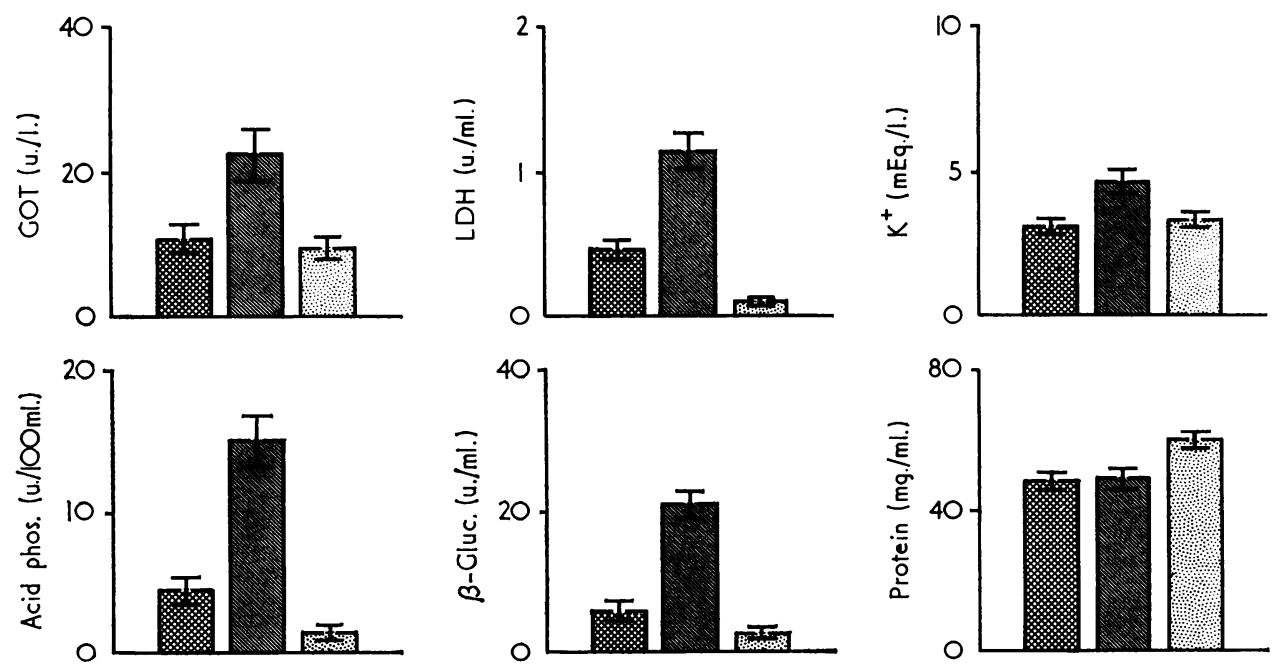

Fig. 5.-Concentrations of protein $\mathrm{K}+$, GOT $\mathrm{LDH}$, acid phos., and $\beta$-gluc. in synovial fluid, with and without centrifugation, and in plasma. Values are the means of thirty results \pm standard errors. 
Pellet.-Centrifugation of the synovial fluid results in the cell-free synovial fluid and a pellet consisting of leucocytes, synovial cells, and debris. In several experiments this pellet was re-suspended in the original volume of saline. The results given in Table III show that, while the kinin-forming activity of the re-suspended cells was only 10 to $60 \mathrm{ng} . / \mathrm{ml}$., the activity of the cell-free supernatant was $300-2,000 \mathrm{ng} . / \mathrm{ml}$. In contrast, the concentration of the intracellular enzymes acid phos., $\beta$-gluc., and GOT was greater in the small volume occupied by the cells than in the whole supernatant.

One possibility was that the cells contained not a kinin-forming enzyme but an activator of such an enzyme. This possibility was tested by incubation of the cells with synovial fluid or with plasma in the presence of excess substrate, but no additional formation could be obtained. In four experiments in which kinin formation in plasma was examined alone and in the presence of cell suspension, the values were $20,240,800,80 \mathrm{ng} . / \mathrm{ml}$. alone, and 60 , $80,1,440,40 \mathrm{ng} . / \mathrm{ml}$. in the presence of cells respectively.

Another possibility to be considered was that the cells contained a kinin-forming enzyme with an acid $\mathrm{pH}$ optimum. However, when the incubations were carried out at $\mathrm{pH} 5$, the small amount of kinins formed ( 3 to $10 \mathrm{ng} . / \mathrm{ml}$.) was no greater than at pH 7.4.
The kininase activity of the cell suspension was small. When incubated with bradykinin at $\mathrm{pH}$ 7.4 kininase activity could only be detected after several hours. No activity could be detected at pH $5 \cdot 0$ even after 20 hours' incubation.

Synovium.-In two patients the enzyme levels in the synovium were examined after synovectomy. The tissue was immediately frozen until it could be homogenized. This was carried out in an Ultra Turrax after adding 2 vol. Tyrode solution per g. tissue. The homogenate was frozen and thawed twice before centrifugation at $14,000 \mathrm{G}$. The supernatant was used for assays of intracellular enzymes and kinin enzymes.

Table IV shows the high concentrations of intracellular enzymes and potassium in the extract of synovium. The kinin-forming activity was low ( 5 to $20 \mathrm{ng} . / \mathrm{ml}$.) when tested at $\mathrm{pH} 7.4$ or $\mathrm{pH}$ $5 \cdot 0$. However, the extracts possessed a high kininase activity, four and thirteen times that of the synovial fluid itself, and this activity was different from that of the plasma kininase since it was not completely inhibited by acid treatment (pH 2 for 10 min.), EDTA $10^{-3} \mathrm{M}$ ), cobalt chloride $\mathrm{CoCl}_{2}$ $\left(3 \times 10^{-2} \mathrm{M}\right)$, or iodo-acetic acid $\left(10^{-3} \mathrm{M}\right)$.

RELATIONSHIP TO DISEASE.-The kinin-forming and kininase activities and kininogen content of samples of synovial fluid collected from patients with RA and Reiter's disease, as seen from the observed range

TABLE III

ENZYME ACTIVITIES IN CELLS OF SYNOVIAL FLUID COMPARED WITH THAT IN THE SUPERNATANT

\begin{tabular}{|c|c|c|c|c|c|c|c|c|c|c|c|}
\hline \multicolumn{2}{|c|}{ Substance Tested } & \multirow{2}{*}{$\begin{array}{c}\begin{array}{c}\text { Acid Phos. } \\
\text { (u./100 ml.) }\end{array} \\
8 \cdot 7 \\
\pm 1.0 \\
\end{array}$} & \multirow{2}{*}{$\begin{array}{c}\beta \text {-gluc. } \\
\text { (u./ml.) } \\
16 \cdot 8 \\
\pm 2 \cdot 5\end{array}$} & \multirow{2}{*}{$\begin{array}{c}\begin{array}{c}\text { LDH } \\
\text { (u./ml.) }\end{array} \\
\begin{array}{r}2 \cdot 00 \\
\pm 0 \cdot 75\end{array}\end{array}$} & \multirow{2}{*}{$\begin{array}{r}\text { GOT } \\
\text { (u./1.) }\end{array}$} & \multirow{2}{*}{$\begin{array}{r}\text { GPT } \\
\text { (u./l.) }\end{array}$} & \multirow{2}{*}{$\begin{array}{c}\begin{array}{c}\mathrm{K}+ \\
(\mathrm{mEq} . / 1 .)\end{array} \\
\begin{array}{r}\mathbf{2} \cdot 9 \\
\pm \mathbf{0 . 4}\end{array}\end{array}$} & \multirow{2}{*}{$\begin{array}{c}\begin{array}{c}\text { Protein } \\
\text { (mg./ml.) }\end{array} \\
45 \cdot 2 \\
\pm 2 \cdot 8\end{array}$} & \multirow{2}{*}{$\begin{array}{c}\begin{array}{c}\text { Kinin-forming } \\
\text { Activity } \\
\text { (ng./ml.) }\end{array} \\
660 \\
\pm 229\end{array}$} & \multirow{2}{*}{$\begin{array}{c}\begin{array}{c}\text { Kininase } \\
\text { (ng./min./ml.) }\end{array} \\
186 \\
\pm 24\end{array}$} & \multirow{2}{*}{$\begin{array}{c}\begin{array}{c}\text { Kininogen } \\
(\mu \mathrm{g} . / \mathrm{ml} .)\end{array} \\
\begin{array}{r}2 \cdot 05 \\
\pm 0.31\end{array}\end{array}$} \\
\hline $\begin{array}{c}\text { Synovial } \\
\text { Fluid }\end{array}$ & $\begin{array}{l}\text { Non- } \\
\text { centrifuged }\end{array}$ & & & & & & & & & & \\
\hline & Centrifuged & $\begin{array}{r}3.5 \\
\pm 0.4\end{array}$ & $\begin{array}{r}5 \cdot 3 \\
\pm 0.4\end{array}$ & $\begin{array}{r}0.39 \\
\pm 0.06\end{array}$ & $\begin{array}{r}4 \cdot 4 \\
\pm 1 \cdot 3\end{array}$ & $\begin{array}{r}0.9 \\
\pm 0.5\end{array}$ & $\begin{array}{r}2.5 \\
\pm 0.2\end{array}$ & $\begin{array}{r}49 \cdot 3 \\
\pm 2 \cdot 3\end{array}$ & $\begin{array}{r}702 \\
\pm 191\end{array}$ & $\begin{array}{r}188 \\
\pm 16\end{array}$ & $\begin{array}{r}2 \cdot 79 \\
\pm 0.53\end{array}$ \\
\hline \multicolumn{2}{|c|}{$\begin{array}{l}\text { Cell } \\
\text { Suspension }\end{array}$} & $\begin{array}{r}5 \cdot 6 \\
\pm 1 \cdot 2\end{array}$ & $\begin{array}{r}37 \cdot 9 \\
\pm 7 \cdot 9\end{array}$ & $\begin{array}{r}0.03 \\
\pm 0.01\end{array}$ & $\begin{array}{r}8 \cdot 1 \\
\pm 2 \cdot 6\end{array}$ & $\begin{array}{r}1.8 \\
\pm 0.6\end{array}$ & $\begin{array}{c}1 \cdot 3 \\
\pm 0.23\end{array}$ & $\begin{array}{r}7 \cdot 8 \\
\pm 1 \cdot 0\end{array}$ & $\begin{array}{r}34 \cdot 2 \\
\pm 5.6\end{array}$ & $\begin{array}{r}31 \\
\pm 8\end{array}$ & $\begin{array}{r}0.35 \\
\pm 0.05\end{array}$ \\
\hline
\end{tabular}

Means of twenty samples \pm standard error. The pellet was re-suspended in a volume of Tyrode solution equal to the original volume of synovial fluid, for measurement of kinin-forming, kininase activity, and kininogen content.

TABLE IV

ENZYME ACTIVITIES IN SYNOVIAL MEMBRANE

\begin{tabular}{|c|c|c|c|c|c|c|c|c|c|}
\hline Synovium & $\begin{array}{l}\text { Acid Phos. } \\
\text { (u. } / 100 \mathrm{ml} .)\end{array}$ & $\begin{array}{l}\beta \text {-gluc. } \\
\text { (u./ml.) }\end{array}$ & $\underset{\text { (u./ml.) }}{\text { LDH }}$ & $\begin{array}{l}\text { GOT } \\
\text { (u./l.) }\end{array}$ & $\begin{array}{l}\text { GPT } \\
\text { (u./1.) }\end{array}$ & $\underset{(\mathrm{mEq} / 1 .)}{\mathrm{K}+}$ & $\begin{array}{c}\text { Protein } \\
\text { (mg./ml.) }\end{array}$ & $\begin{array}{l}\text { Kinin-forming } \\
\text { Activity } \\
\text { (ng./ml.) }\end{array}$ & $\underset{\text { (ng./min./ml.) }}{\text { Kininase }}$ \\
\hline$\frac{1}{2}$ & $\begin{array}{r}6,000 \\
112\end{array}$ & $\begin{array}{r}281 \\
19\end{array}$ & $\begin{array}{l}35 \cdot 4 \\
11 \cdot 3\end{array}$ & $\begin{array}{r}113 \\
34\end{array}$ & $\begin{array}{l}15 \\
12\end{array}$ & $\begin{array}{l}46 \cdot 5 \\
108\end{array}$ & $\begin{array}{l}22 \cdot 8 \\
26 \cdot 5\end{array}$ & 20 & $\begin{array}{r}2,470 \\
656\end{array}$ \\
\hline
\end{tabular}

The synovial membranes were homogenized in 2 vol. Tyrode solution per $\mathrm{g}$. tissue and centrifuged. 
of values given in Table $\mathrm{V}$, showed a great deal of individual variation, but the mean values were about the same in each group of patients.

\section{Biochemical'Activity}

INTRACELLULAR ENZYMES.-The mean results of thirty samples of synovial fluid and 26 samples of plasma from 26 patients are illustrated in Fig. 5 (see p. 502). In contrast to the findings in case of kinin-forming and kininase activities, the mean acid phos. $\beta$-gluc., LDH, and GOT activities were not only found to be the highest in synovial fluid containing cells, but they were also higher in cell-free synovial fluid than in plasma.

The cell-pellets also revealed a significantly higher acid phos., $\beta$-gluc., and GOT activities than in plasma, the only exception being LDH. However, as shown in Table IV (above), the synovium was found to contain the highest activities for all the intracellular enzymes.

These findings indicate that the intracellular enzymes may originate not only from the cells present in the synovial fluid but also from those in the synovium lining the joint cavity.
Relationship between lysosomal and cytoplasmic enzymes.-In Fig. 6 (opposite) the acid phos. activity in the non-centrifuged synovial fluid is compared with activities of $\beta$-gluc., LDH, GOT, and protein concentration in the same samples of synovial fluid. There is a significant correlation between acid phos. and $\beta$-gluc., LDH, and GOT activities, but the degree of correlation between acid phos. and $\beta$-gluc. activities is no greater than that between acid phos. and LDH or GOT activities. These data lead us to conclude that increases in the activity of intracellular enzymes in joint diseases are not chiefly confined to those of the lysosomal compartment.

Relationship between disease and composition of synovial fluid and plasma.-The protein concentrations and the activities of acid phos., $\beta$-gluc., LDH, and GOT in the cell-containing synovial fluid and plasma collected from all patients are given in Table VI.

In this investigation we were unable to obtain samples of normal synovial fluid with which to compare the fluid collected from the five groups of patients. However, the results (Table VI) revealed that, although the concentration of protein and the

TABLE V

COMPARISON OF KININOGEN CONTENT, KININ-FORMING, AND KININASE ACTIVITY OF PLASMA AND SYNOVIAL FLUID OF PATIENTS WITH RA AND REITER'S DISEASE

\begin{tabular}{|c|c|c|c|c|c|c|c|c|}
\hline & \multirow{2}{*}{$\begin{array}{l}\text { Disease } \\
\text { Category }\end{array}$} & \multirow{2}{*}{$\begin{array}{c}\text { No. of } \\
\text { Determina- } \\
\text { tions }\end{array}$} & \multicolumn{2}{|c|}{$\begin{array}{l}\text { Kinin-Forming Activity } \\
\text { (ng./ml.) }\end{array}$} & \multicolumn{2}{|c|}{$\begin{array}{l}\text { Kininase Activity } \\
\text { (ng./ml.) }\end{array}$} & \multicolumn{2}{|c|}{$\begin{array}{c}\text { Kininogen Content } \\
(\mu \mathrm{g} . / \mathrm{ml} .)\end{array}$} \\
\hline & & & Synovial Fluid & Plasma & $\overline{\text { Synovial Fluid }}$ & Plasma & $\overline{\text { Synovial Fluid }}$ & Plasma \\
\hline \multirow[b]{2}{*}{ RA } & "Classical" & 13 & $\begin{array}{c}544 \\
(200-1,280)\end{array}$ & $\begin{array}{c}1,122 \\
(800-2,320)\end{array}$ & $\begin{array}{c}1 \cdot 69 \\
(0 \cdot 79-3 \cdot 14)\end{array}$ & $\begin{array}{c}1 \cdot 72 \\
(0 \cdot 96-1 \cdot 95)\end{array}$ & $\begin{array}{c}3 \cdot 17 \\
(0 \cdot 56-5 \cdot 0)\end{array}$ & $\begin{array}{c}6 \cdot 3 \\
(0 \cdot 70-12 \cdot 2)\end{array}$ \\
\hline & $\begin{array}{l}\text { "Probable", and } \\
\text { "Possible" }\end{array}$ & 7 & $\begin{array}{c}533 \\
(480-640)\end{array}$ & 二 & $\begin{array}{c}1 \cdot 63 \\
(0 \cdot 75-2 \cdot 72)\end{array}$ & - & $\begin{array}{c}2 \cdot 47 \\
(0 \cdot 84-4 \cdot 70)\end{array}$ & - \\
\hline \multicolumn{2}{|c|}{ Reiter's Disease } & 6 & $\begin{array}{c}670 \\
(320-1,280)\end{array}$ & $\begin{array}{c}1,120 \\
(800-1,600)\end{array}$ & $\begin{array}{c}1 \cdot 40 \\
(0 \cdot 76-2 \cdot 23)\end{array}$ & $\begin{array}{c}2 \cdot 05 \\
(1 \cdot 39-2 \cdot 80)\end{array}$ & $\begin{array}{c}2 \cdot 31 \\
(1 \cdot 6-4 \cdot 2)\end{array}$ & $\begin{array}{l}4 \cdot 2 \\
(0 \cdot 50-8 \cdot 4)\end{array}$ \\
\hline
\end{tabular}

(values given are mean and observed range)

RELATIONSHIP BETWEEN DISEASE AND

\begin{tabular}{|c|c|c|c|c|c|c|c|}
\hline \multirow{2}{*}{\multicolumn{2}{|c|}{$\begin{array}{l}\text { Disease } \\
\text { Category }\end{array}$}} & \multicolumn{2}{|c|}{$\begin{array}{c}\text { No. of } \\
\text { Determinations }\end{array}$} & \multicolumn{2}{|c|}{$\begin{array}{l}\text { Acid Phos. } \\
\text { (u./100 ml.) }\end{array}$} & \multicolumn{2}{|c|}{$\begin{array}{l}\beta \text {-gluc. } \\
\text { (u./ml.) }\end{array}$} \\
\hline & & Synovial Fluid & Plasma & Synovial Fluid & Plasma & Synovial Fluid & Plasma \\
\hline \multirow{2}{*}{ RA } & "Classical" & 65 & 40 & $18 \cdot 4 \pm 17 \cdot 3$ & $1 \cdot 9 \pm 2 \cdot 3$ & $23 \cdot 0 \pm 14 \cdot 9$ & $5 \cdot 2 \pm 8 \cdot 2$ \\
\hline & $\begin{array}{l}\text { "Probable" and } \\
\text { "Possible" }\end{array}$ & 12 & 9 & $13 \cdot 6 \pm 8 \cdot 4$ & $1 \cdot 6 \pm 1 \cdot 4$ & $11 \cdot 7 \pm 7 \cdot 1$ & $3 \cdot 2 \pm 2 \cdot 6$ \\
\hline \multicolumn{2}{|c|}{ Osteoarthrosis } & 10 & 9 & $4 \cdot 3 \pm 2 \cdot 8$ & $1 \cdot 8 \pm 1 \cdot 5$ & $7 \cdot 0 \pm 1 \cdot 9$ & $4 \cdot 4 \pm 2 \cdot 1$ \\
\hline \multicolumn{2}{|c|}{ Reiter's Disease } & 11 & 8 & $7 \cdot 6 \pm 6 \cdot 2$ & $2 \cdot 9 \pm 1 \cdot 8$ & $21 \cdot 1 \pm 14 \cdot 0$ & $2 \cdot 8 \pm 1 \cdot 8$ \\
\hline \multicolumn{2}{|c|}{ Arthritis with Psoriasis } & 7 & 7 & $23 \cdot 1 \pm 11 \cdot 9$ & $2 \cdot 6 \pm 1 \cdot 9$ & $28 \cdot 0 \pm 19 \cdot 7$ & $3 \cdot 6 \pm 2 \cdot 2$ \\
\hline
\end{tabular}

Values given are Means \pm Standard Deviation 

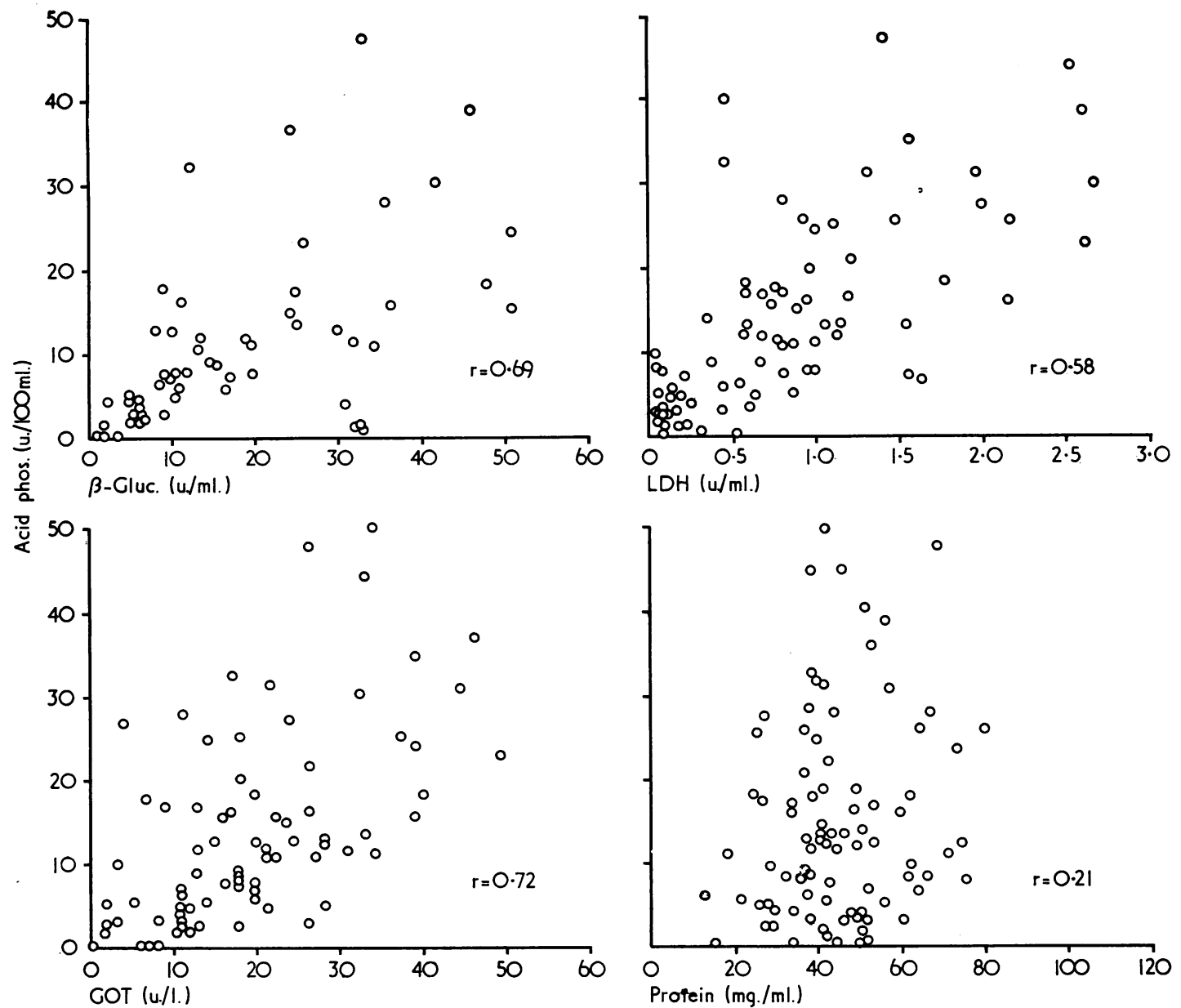

Fig. 6.-Concentrations in samples of cell-containing synovial fluid of acid phosphatase plotted against the concentrations of $\beta$-gluc., LDH $\mathrm{GOT}$, and protein; $r=$ coefficient of correlation.

VI COMPOSITION OF SYNOVIAL FLUID AND PLASMA

\begin{tabular}{|c|c|c|c|c|c|c|c|}
\hline \multicolumn{2}{|c|}{$\underset{\text { (u./ml.) }}{\text { LDH }}$} & \multicolumn{2}{|c|}{$\begin{array}{l}\text { GOT } \\
\text { (u./1.) }\end{array}$} & \multicolumn{2}{|c|}{$\begin{array}{l}\text { GPT } \\
\text { (u./1.) }\end{array}$} & \multicolumn{2}{|c|}{$\underset{(\mathrm{mg} . / \mathrm{ml} .)}{\text { Protein }}$} \\
\hline Synovial Fluid & Plasma & Synovial Fluid & Plasma & Synovial Fluid & Plasma & Synovial Fluid & Plasma \\
\hline $1 \cdot 41 \pm 1 \cdot 85$ & $0.11 \pm 0.08$ & $24 \cdot 2 \pm 13 \cdot 6$ & $11 \cdot 1 \pm 8 \cdot 1$ & $5 \cdot 2 \pm 4 \cdot 5$ & $16 \cdot 8 \pm 8 \cdot 0$ & $49 \cdot 3 \pm 13 \cdot 8$ & $61 \cdot 2 \pm 16 \cdot 3$ \\
\hline $0.62 \pm 0.64$ & $0.07 \pm 0.03$ & $14 \cdot 3 \pm 6 \cdot 6$ & $16 \cdot 0 \pm 8.9$ & $3 \cdot 2 \pm 2 \cdot 8$ & $15 \cdot 6 \pm 7 \cdot 6$ & $39 \cdot 6 \pm 8 \cdot 1$ & $61 \cdot 6 \pm 10 \cdot 1$ \\
\hline $0.21 \pm 0.18$ & $0.06 \pm 0.04$ & $10 \cdot 3 \pm 8 \cdot 2$ & $10 \cdot 0 \pm 4.9$ & $1 \cdot 8 \pm 1 \cdot 2$ & $9 \cdot 4 \pm 4 \cdot 2$ & $34 \cdot 0 \pm 11 \cdot 1$ & $63 \cdot 1 \pm 12 \cdot 1$ \\
\hline $0.29 \pm 0.22$ & $0.08 \pm 0.12$ & $15 \cdot 5 \pm 10 \cdot 4$ & $15 \cdot 4 \pm 9 \cdot 0$ & $2 \cdot 5 \pm 1 \cdot 9$ & $8 \cdot 5 \pm 3 \cdot 8$ & $45 \cdot 5 \pm 12 \cdot 3$ & $64 \cdot 5 \pm 11 \cdot 2$ \\
\hline $1.42 \pm 0.98$ & $0.07 \pm 0.05$ & $19 \cdot 1 \pm 9 \cdot 6$ & $7 \cdot 5 \pm 6 \cdot 0$ & $2 \cdot 8 \pm 1 \cdot 8$ & $17 \cdot 8 \pm 10 \cdot 4$ & $40 \cdot 0 \pm 14 \cdot 4$ & $61 \cdot 1 \pm 12 \cdot 5$ \\
\hline
\end{tabular}


enzyme activity in the synovial fluid varied with the type of arthritis, the plasma levels remained relatively constant. Therefore the relationship between the plasma and synovial fluid constituents provides a measure of the biochemical changes taking place in the joint space as a result of synovial inflammation.

The acid phos., $\beta$-gluc., and LDH activities were significantly higher than the plasma levels in all five disease categories $(\mathrm{P}<0.05$ in osteoarthrosis, and $P<0.001$ for all other diseases). The mean total GOT activity was higher than the plasma values in patients with "classical" RA and with arthritis with psoriasis, but the differences were statistically significant in "classical" RA only $(P<0 \cdot 05)$. The total GPT activity remained the same or was lower than the plasma values in all the diseases.

The lowest concentration of protein and of all the intracellular enzymes examined were observed in osteoarthrotic synovial fluid, whereas the highest values were found in the painful knees of patients with "classical" RA. The synovial fluid changes in "probable" and "possible" RA were intermediate between those observed in OA and those in "classical" RA.

The composition of seven samples of synovial fluid from four patients with arthritis and psoriasis closely resembled that in patients with "classical" RA. The mean acid phos. activity in synovial fluid was nine times the mean plasma values in both the diseases; $\beta$-gluc. was eight times the mean plasma level in psoriatics and four times that in "classical" RA; LDH was twelve and twenty times higher than the plasma levels in "classical" RA and in psoriatics respectively; GOT was twice the plasma values in both diseases.

In Reiter's disease the mean acid phos. and LDH levels in synovial fluid were lower than in the other three inflammatory joint disorders: "classical" RA, "probable" and "possible" RA, and arthritis with psoriasis. Seven out of eleven specimens examined revealed acid phos. activities comparable with those found in osteoarthrosis. These findings are surprising in view of the fact that patients with Reiter's disease had clinical evidence of acute knee joint inflammation as well as synovial fluid protein concentration and $\beta$-gluc. activity comparable with those found in patients with "classical" RA.

LEUCOCYTE COUNTS.-These were also the lowest in osteoarthrotics and ranged from $0-1,200$ per $\mathrm{mm} .^{3}$, fewer than 20 per cent. of these being polymorphonuclear in type. This was in marked con- trast to the cytological findings in "classical" RA patients in whom the counts ranged from 300 to 26,000 per $\mathrm{mm}^{3}{ }^{3}$, polymorphonuclear forms accounting for nearly 85-90 per cent. of the total. Patients with "probable" and "possible" RA had 250-8,500 leucocytes per $\mathrm{mm}^{3}$, less than 60 per cent. being polymorphonuclear. In patients with Reiter's disease the synovial fluid contained 2,800 to 18,500 leucocytes per $\mathrm{mm}^{3}$, approximately 50 per cent. being mononuclear in type. Psoriatic patients had 500 to 11,700 leucocytes per mm. ${ }^{3}$ but no consistent morphological pattern. In addition, all the synovial fluid samples, including those from the osteoarthrotics, contained cellular debris and synovial lining cells which were not counted.

RELATIONSHIP BETWEEN FREE AND TOTAL ACTIVITY. -In the present study, the enzyme activity measurable in the cell-free centrifuged synovial fluid has been used as an index of free activity whereas that obtained in cell-containing non-centrifuged synovial fluid has been taken to reflect the total activity.

A comparison of the free and total acid phos., $\beta$-gluc., LDH, and GOT activities, shown in Table VII (opposite), revealed that in all the five diseases the free activities were considerably lower than the corresponding total activities.

In patients with osteoarthrosis, "probable" and "possible" RA, and Reiter's disease, the free activities of all four enzymes were found to be equal to or lower than the corresponding plasma values given in Table V. These observations suggest that the enzyme activities in the synovial fluid from patients with osteoarthrosis, "probable" and "possible" RA, and Reiter's disease were chiefly confined to the cellular compartment.

The relationship between the free and total activities and plasma in patients with "classical" RA and arthritis with psoriasis was somewhat different, and varied from one intracellular enzyme to another. The free acid phos. and $\beta$-gluc. activities in "classical" RA and psoriasis were higher than the plasma values, but the mean differences were statistically significant in both the diseases only in respect of acid phos. $(P<0.05)$. The free LDH, and, to a lesser extent, the GOT activities, were also higher than the plasma levels, but the differences were not statistically significant. Thus, in "classical" RA and arthritis with psoriasis, an appreciable leakage of intracellular enzymes had occurred in respect of acid phos., $\beta$-gluc., and LDH, and to a lesser extent of GOT.

In Reiter's disease, although the total acid phos. and $\beta$-gluc. activity was less than in RA, the enzyme 
TABLE VII

FREE AND TOTAL ENZYME ACTIVITIES IN SYNOVIAL FLUID

\begin{tabular}{|c|c|c|c|c|c|c|c|c|c|c|}
\hline & \multirow{2}{*}{$\begin{array}{l}\text { Disease } \\
\text { Category }\end{array}$} & \multirow{2}{*}{$\begin{array}{c}\text { No. of } \\
\text { Determi- } \\
\text { nations }\end{array}$} & \multicolumn{2}{|c|}{$\begin{array}{l}\text { Acid phos. } \\
\text { (u./100 ml.) }\end{array}$} & \multicolumn{2}{|c|}{$\begin{array}{l}\beta \text {-gluc. } \\
\text { (u./ml.) }\end{array}$} & \multicolumn{2}{|c|}{$\begin{array}{c}\text { LDH } \\
\text { (u./ml.) }\end{array}$} & \multicolumn{2}{|c|}{$\begin{array}{l}\text { GOT } \\
(u . / 1 .)\end{array}$} \\
\hline & & & Free & Total & Free & Total & Free & Total & Free & Total \\
\hline $\mathbf{R A}$ & $\begin{array}{l}\text { "Classical } \\
\text { "Probable" and } \\
\text { "Possible" }\end{array}$ & $\begin{array}{r}31 \\
7\end{array}$ & $\begin{array}{l}5 \cdot 1 \pm 1 \cdot 7 \\
2 \cdot 8 \pm 0 \cdot 6\end{array}$ & $\begin{array}{r}12 \cdot 8 \pm 1 \cdot 6 \\
9 \cdot 0 \pm 1 \cdot 8\end{array}$ & $\begin{array}{l}7 \cdot 7 \pm 1 \cdot 4 \\
4 \cdot 2 \pm 0 \cdot 9\end{array}$ & $\begin{array}{l}22 \cdot 2 \pm 2 \cdot 6 \\
12 \cdot 8 \pm 2 \cdot 7\end{array}$ & $\begin{array}{l}0.50 \pm 0 \cdot 17 \\
0.20 \pm 0.06\end{array}$ & $\begin{array}{l}1 \cdot 51 \pm 0.23 \\
0.96 \pm 0 \cdot 15\end{array}$ & $\begin{array}{r}13 \cdot 2 \pm 2 \cdot 9 \\
9 \cdot 5 \pm 1 \cdot 7\end{array}$ & $\begin{array}{l}22 \cdot 6 \pm 3 \cdot 2 \\
15 \cdot 6 \pm 2 \cdot 8\end{array}$ \\
\hline \multicolumn{2}{|c|}{ Osteoarthrosis } & 4 & $0.9 \pm 0.3$ & $3 \cdot 9 \pm 0 \cdot 7$ & $1 \cdot 1 \pm 0 \cdot 5$ & $5 \cdot 3 \pm 1 \cdot 4$ & $0.11 \pm 0.02$ & $0.22 \pm 0.06$ & $6 \cdot 2 \pm 1 \cdot 7$ & $10 \cdot 8 \pm 2 \cdot 7$ \\
\hline \multicolumn{2}{|c|}{ Reiter's Disease } & 5 & $1 \cdot 4 \pm 0 \cdot 5$ & $9 \cdot 8 \pm 1 \cdot 8$ & $3 \cdot 2 \pm 0 \cdot 8$ & $20 \cdot 1 \pm 4 \cdot 8$ & $0.08 \pm 0.02$ & $0.38 \pm 0.09$ & $10 \cdot 0 \pm 2 \cdot 7$ & $26 \cdot 2 \pm 3 \cdot 8$ \\
\hline \multicolumn{2}{|c|}{$\begin{array}{l}\text { Arthritis and } \\
\text { Psoriasis }\end{array}$} & 5 & $9 \cdot 2 \pm 2 \cdot 3$ & $27 \cdot 3 \pm 5 \cdot 2$ & $10 \cdot 8 \pm 4 \cdot 7$ & $31 \cdot 9 \pm 8 \cdot 5$ & $0.89 \pm 0.21$ & $1 \cdot 87 \pm 0 \cdot 28$ & $14 \cdot 2 \pm 3 \cdot 2$ & $24 \cdot 5 \pm 4 \cdot 1$ \\
\hline
\end{tabular}

Enzyme activities measurable in the cell-free supernatant synovial fluid have been defined as FREE and those measurable in the cell-containing non-centrifuged synovial fluid as TOTAL. Values given are means \pm standard error.

activity still retained in the cells was about the same, and this may well reflect a lower degree of injury to synovial lining cells as well as of the inflammatory cells in this joint disease. The apparent stability of the cells in Reiter's disease is not the result of therapy, since most of these patients were being treated in the same way as those with rheumatoid arthritis.

\section{Discussion}

The present results indicate that the major constituents of the kinin-system are present in pathological joint fluid. The concentration of kininogen in synovial fluid was considerably lower than in plasma even allowing for the difference in the concentration of protein between the two body fluids. This finding could be a reflection of the utilization of kininogen in the formation of kinins during the chronic inflammation. On the other hand, the kinin-forming activity in synovial fluid following mild activation with dilution or glass contact or after stronger activation by lowering $\mathrm{pH}$, was also found to be lower than the plasma activities. It is possible therefore that these low activities indicate a low kinin-forming potential in the joint which could not be consistent with the view that kinins play a major role in joint inflammation.

The relevance of the free kinin activity found in synovial fluid is doubtful. The extent of free kinin activity in a body fluid is not only due to the kinin-forming activity but also depends on the kininase activity in the same fluid. The present results show that kininase activity is as high in synovial fluid as in plasma. The synovium itself might well be the richest, and an as yet unidentified, source of kininase in the joint.
In view of the high kininase activity in the synovial fluid and the synovium, it seems unlikely that free kinins will be found in the fluid even from acutely inflamed joints, as the peptides would be inactivated almost as quickly as they were formed and had exerted their pharmacological action. It is, therefore, difficult to assess the significance of the finding of Melmon, Webster, Goldfinger, and Seegmiller (1967) that the amount of free kinins present in rheumatoid synovial fluid "seemed to correlate well with the severity of symptoms in selected individual patients".

Removal of cells present in the synovial fluid by centrifugation did not alter the kinin-forming or kininase activities, both of which remained the same in cell-free and cell-containing synovial fluid. These data strongly suggest, that contrary to previous reports (Eisen, 1966; Greenbaum and Kim, 1967; Melmon and Cline, 1967; and Zachariae and others, 1966), the kinin enzymes in inflammatory joint fluid are not derived from cells present in the synovial fluid.

The suggestion is strengthened even more by the observations that, in comparison with the findings in cell-free synovial fluid, only small amounts of kinin-forming and kininase activities were detectable in the cell-pellet which contained many polymorphonuclear leucocytes, cell debris, and synovial cells. In contrast, removal of cells from the synovial fluid lowered significantly the acid phos., $\beta$-gluc., LDH, and GOT activities. Moreover, the activities of three out of the four enzymes in the pellet were found to be in excess of those observed in the cell-free synovial fluid. The exception was the activity of LDH which was found to be particularly low in all the samples of cell pellet examined, a problem which requires further biochemical investigation. 
Greenbaum and Kim (1967) have described a kinin-forming enzyme in leucocytes which has an acid pH optimum and is not inhibited by soya bean trypsin inhibitor. However, the present investigation has shown that on neither of these criteria could the kinin-forming activity of synovial fluid be attributed to this enzyme. On the contrary, the nature of the kinin-forming enzyme in the synovial fluid resembles that found in plasma-it acts better at pH $7 \cdot 4$ than at pH $5 \cdot 0$, and it is inhibited by soya bean trypsin inhibitor. The possibility that the cells of the synovial fluid contained an activator of the kinin-forming enzymes was also excluded.

The polymorphonuclear leucocytes have also been reported to contain kininase activity (Eisen, 1966; Zachariae and others, 1966; Greenbaum and Kim, 1967; Melmon and Cline, 1967). As this leucocyte kininase is not inhibited by EDTA but is inhibited by DFP, while that in synovial fluid is inhibited by EDTA but not by DFP, there seems little doubt that the kininase activity of synovial fluid is not due to this intracellular kininase.

Furthermore, as the kininase in synovial fluid has a very low activity at $\mathrm{pH} 5 \cdot 0$, it is distinguishable from the catheptic kininase described by Greenbaum and Yamafuji (1966) which has a pH optimum of about $\mathrm{pH} 5 \cdot 0$. It is possible that the kininase activity found in the synovium itself, which was different from that in the synovial fluid or plasma, can be attributed to one of these intracellular enzymes but enough experimental data have not yet been collected to assess this point. As this kininase activity does not appear to be associated with the cells in the synovial fluid, either in the non-centrifuged suspension or in the pellet after centrifugation, it seems likely that the kininase of the synovium does not originate in the same cells as do acid phos., $\beta$-gluc., LDH, or GOT, and that it might even form part of the structural elements of the synovium.

The highest increases in the intracellular enzyme activities were present in patients with "classical" RA and arthritis with psoriasis. In addition, an appreciable leakage of the enzymes (as reflected by the presence in the cell-free synovial fluid of activities higher than those in the plasma) was observed in these two groups of patients only. Thus, the hypothesis of Weissmann (1967) that the release of lysosomal enzymes may be the final common pathway for mediation of joint injury in the rheumatic diseases is not supported by these findings, as leakage of lysosomal enzymes were observed in only two of the five disease categories studied. Furthermore, cytoplasmic as well as lysosomal enzymes leaked out of the cells, which indicates loss of the permeability of the whole cell rather than of the lysosomes only.

The finding that the highest intracellular enzyme activities were seen in joints of patients with "classical" RA and the lowest in those with osteoarthrosis agrees with many other studies (Jacox and Feldmahn, 1955; Vesell, Osterland, Bearn, and Kunkel, 1962; Quatrini and Pignataro, 1962; West, Poske, Black, Pilz, and Zimmerman, 1963; Lehman, Kream, and Brogna, 1964; Caygill and Pitkeathly, 1966).

In the present study it has also been shown that high enzyme levels are present in the joints of patients with psoriasis. Most surprising of all was the finding that, in patients with Reiter's disease, activities of intracellular enzymes were generally low. The protein concentration and leucocyte counts in patients with this disease were comparable with those of patients with RA-this was consistent with the inflamed condition of the joints in Reiter's disease. But, when we consider the distribution of the intracellular enzymes between cells and supernatant in the joints, it is clear that the difference between RA and Reiter's disease lies in the supernatant and not in the cells. This might well reflect the clinical difference between RA and Reiter's disease; i.e. in RA there is a more marked and sustained hypertrophy of the synovium. Such a view would imply that the increased levels of enzymes in the supernatants from RA joints originates mainly in the synovial lining cells. There was a considerable overlap between the individual enzyme activities in the different diseases, which indicates that measurement of the enzyme activities in synovial fluid has little practical usefulness in the definitive diagnosis of arthritis; an important conclusion also made by Ziff, Simson, Scull, Smith, Shatton, and Mainland (1955) who examined the activity of aminotripeptidase, glycylglycylglycinase in six different joint diseases.

\section{Summary}

(1) The activity of intracellular enzymes and of the enzymes of the kinin system has been examined in synovial fluid collected from patients with rheumatoid arthritis and related diseases.

(2) Although the mean activities of the intracellular enzymes varied with the disease, those of the kinin enzymes did not. However, the measurement of enzyme activities in the synovial fluid 
would not constitute a reliable diagnostic aid because of the considerable overlap of individual values in patients with different diseases.

(3) The cell-containing, but not the cell-free, synovial fluid in all the joint diseases including osteoarthrosis was found to have acid phosphatase, $\beta$-glucuronidase, and lactic dehydrogenase activity significantly higher than the corresponding plasma activities. On the other hand, enzymes of the kinin system were present in centrifuged and non-centrifuged synovial fluid in about the same concentration, which was lower than the plasma levels.

(4) In the joints of patients with "classical" rheumatoid arthritis and psoriasis, the activity of intracellular enzymes was higher in cell-free synovial fluid than in plasma. However, not only were the activities of lysosomal enzymes increased, but those of other intracellular enzymes as well. This indicates an alteration in the permeability of the whole cell or cell death rather than any specific alteration of the lysosomal membrane.

(5) Although the pellet obtained after centrifugation of synovial fluid contained high concentrations of intracellular enzymes, it contained only small amounts of kinin enzymes. In addition, the $\mathrm{pH}$ optimum and sensitivity to inhibitors of the kinin-forming and kininase enzymes in synovial fluid resemble those of kinin enzymes in plasma and not those reported for kinin enzymes present in polymorphonuclear leucocytes.

(6) It is concluded that the kinin-forming and kininase enzymes in synovial fluid are derived mainly from plasma and not from invading leucocytes.

The authors wish to acknowledge the technical assistance of Mr. N. Bowery and Mrs. Pamela Holmes, CIBA Laboratories Limited, and the helpful advice of Dr. W. Watson Buchanan, Physician, Centre for Rheumatic Diseases, Glasgow. Dr. M. K. Jasani was in receipt of a CIBA Clinical Research Fellowship.

Dr. M. Katori is now at the Institute for Cardiovascular Diseases, Tokyo Medical and Dental University, Japan.

\section{DISCUSSION}

DR. P. J. L. Holt (Hammersmith): It has always seemed to me that measuring the enzyme content of the cells from the fixed quantity of synovial fluid, e.g. $5 \mathrm{ml}$., would be of a much better estimate of inflammation than measuring fluid levels.

DR. JASANI: We measured the enzyme activity of the cells re-suspended in the same volume of physiological saline as the original fluid. Enzyme activity was higher in the cells than in the supernate and it was highest in the cells from acutely inflamed joints.
A SPEAKER: If you froze whole fluid, then release of enzymes from cells into fluid would occur on thawing and you would therefore get higher values than were actually present.

DR. JASANI: Fresh fluid was centrifuged as soon as possible after withdrawal and the supernatant fluid frozen. Assay of enzyme activity was taken as free activity. Whole fluid was also frozen and its enzyme content was taken to be the total activity. Microscopic examination of the supernate was also undertaken to exclude the presence of cells in this fluid.

DR. A. ST. J. Drxon (Bath): Knowing the rapidity with which effusions appear and disappear, presumably your measurement represents a balance between what is being formed and what is being absorbed from the joint. Have you studied the effect of this turnover of synovial fluid and would it be possible to measure the turnover by a labelling technique?

DR. JASANI: I can think of no method whereby this could be done at the present time.

Prof. C. A. Keele (Middlesex Hospital): How did you measure the kinin-forming activity. Was it induced or a naturally occurring activity?

DR. Lewis: We activated the enzyme systems by acidification, glass activation, or dilution methods, and concluded that acidification was the most effective. This method was also found to inhibit kininase activity. We were therefore measuring the active enzyme plus induced enzyme activity.

Prof. Kefle: In fact, you were measuring potential kinin-forming activity.

\section{DR. LEWIS: I agree.}

Prof. Keele: Ideally what we should like to know is how much kinin-forming activity is present immediately after withdrawal of fluid from the joint.

DR. LEWIS: This is true but it is a very difficult job to tackle.

DR. M. I. V. JAYSON (Bath): In some preliminary studies we have done we have found the levels of acid phosphatase and beta glucuronidase are not related to the clinical activity of the joint in rheumatoid arthritis and I would welcome your comments on this point.

Dr. JASANI: The results of this study would confirm your observation.

DR. JAYSON: One further question. Were you able to correlate the levels you obtained with the drug treatment at the time? 
DR. JASANI: We did not attempt a formal study, but we compared the total activities between an aspirintreated and a corticosteroid-treated group. There was no statistical difference between the two groups in the case of any of the enzymes studied, but it was noted that the activity tended to be a little higher in the corticosteroid-treated group, irrespective of the type of enzymes studied.

Prof. K. W. Walton (Birmingham): Since these enzymes are present in the plasma and in the synovial cells in the fluid, would it be possible to try to relate the enzyme activity to some parameter of the permeability of the joint? One method might be to try to relate enzyme activity to the protein content in the joint fluid.

DR. JASANI: We did in fact measure two parameters, vascular permeability by means of total protein content and cell permeability as measured by the potassium content of the fluid and plasma. No correlation was found between protein content and acid phosphatase activity.

\section{REFERENCES}

Amundsen, E., and Nustad, K. (1964). Brit. J. Pharmacol., 23, 440 (Kinin-forming and destroying activities of saliva).

Beck, J. S. (1961). Lancet, 1, 1203 (Variations in the morphological patterns of "autoimmune" nuclear fluorescence).

Brocklehurst, W. E., and Mawer, G. E. (1966). Brit. J. Pharmacol., 27, 256 (The purification of a kininogen from human plasma).

Caygill, J. C., and Pitkeathly, D. A. (1966). Ann. rheum. Dis., 25, 137 (A study of $\beta$-acetylglucosaminase and acid phosphatase in pathological joint fluids).

Diniz, C. R., and Carvalho, I. F. (1963). Ann. N.Y. Acad. Sci., 104, 77 (A micromethod for determination of bradykininogen under several conditions).

Eisen, V. (1966). Proc. roy. Soc. Med., 59, 302 (Urates and kinin formation in synovial fluid).

Elliott, D. F., and Lewis, G. P. (1965). Biochem. J., 95, 437 (Methionyl-lysyl-bradykinin, a new kinin from ox blood).

Fishman, W. H. (1963). In "Methods of Enzymatic Analysis", ed. H. U. Bergmeyer, p. 869. Academic Press, New York and London.

Frey, E. K., Kraut, H., and Werle, E. (1950). "Kallikrein: Padutin". Enke, Stuttgart.

Greenbaum, L. M., and Kim, K. S. (1967). Brit. J. Pharmacol., 29, 238 (The kinin-forming and kininase activities of rabbit polymorphonuclear leucocytes).

- and Yamafuji, K. (1955). Ibid., 27, 230 (The in vitro inactivation and formation of plasma kinins by spleen cathepsins).

Harrison, G. A. (1957). In "Chemical Methods in Clinical Medicine", 4th ed., p. 387. Churchill, London.

Heller, G., Jacobson, A. S., and Kolodny, M. H. (1949). Proc. Soc. exp. Biol. (N.Y.), 72, 316 (A modification of the hemagglutination test for rheumatoid arthritis).

Jacox, R. F., and Feldmahn, A. (1955). J. clin. Invest., 34, 263 (Variations of beta-glucuronidase concentration in abnormal human synovial fluid).

Karmen, A., Wróblewski, F., and LaDue, J. S. (1955). Ibid., 34, 126 (Transaminase activity in human blood).

Lehman, M. A., Kream, J., and Brogna, D. (1964). J. Bone Jt Surg., 46A, 1732 (Acid and alkaline phosphatase activity in the serum and synovial fluid of patients with arthritis).

Lewis, G. P. (1964). Ann. N.Y. Acad. Sci., 116, 847 (Plasma kinins and other vasoactive compounds in acute inflammation).

Lowry, O. H., Rosebrough, N. J., Farr, A. L., and Randall, R. J. (1951). J. biol. Chem., 193, 265 (Protein measurement with Folin phenol reagent). 
Melmon, K. L., and Cline, M. J. (1967). Nature, 213, 90 (Interaction of plasma kinins and granulocytes).

—, Webster, M. E., Goldfinger, S. E., and Seegmiller, J. E. (1967). Arthr. and Rheum., 10, 13 (The presence of a kinin in inflammatory synovial effusion from arthritides of varying etiologies).

Quatrini, U., and Pignataro, P. (1962). Boll. Soc. ital. Biol. sper., 38, 169 (Attività latticodeidrogenasica nei liquidi articolari umani del ginocchio).

Ropes, M. W., Bennett, G. A., Cobb, S., Jacox, R., and Jessar, R. A. (1959). Ann. rheum. Dis., 18, 49 (1958 Revision of diagnostic criteria for rheumatoid arthritis).

Vesell, E. S., Osterland, K. C., Bearn, A. G., and Kunkel, H. G. (1962). J. clin. Invest., 41, 2012 (Isosymes of lactic dehydrogenase; their alterations in arthritis synovial fluid and sera).

Weissmann, G. (1967). Ann. Rev. Med., 18, 97 (The role of lysosomes in inflammation and disease).

West, M., Poske, R. M., Black, A. B., Pilz, C. G., and Zimmerman, H. J. (1963). J. Lab. clin. Med., 62, 175 (Enzyme activity in synovial fluid).

Wróblewski, F., and LaDue, J. S. (1956). Proc. Soc. exp. Biol. (N.Y.), 91, 569 (Serum glutamic pyruvic transaminase in cardiac and hepatic disease).

Zachariae, H., Malmquist, J., and Oates, J. A. (1966). Life Sci., 5, 2347 (Kininase in human polymorphonuclear leukocytes).

Ziff, M., Simson, J., Scull, E., Smith, A., Shatton, J., and Mainland, D. (1955). J. clin. Invest. 34, 27 (Aminotripeptidase content of synovial fluid in arthritis diseases).

Les enzymes intracellulaires et les enzymes kinins dans le liquide synovial des maladies des articulations

Leur origine ainsi que leur relation à la catégorie de la maladie

RÉSUMÉ

(1) L'activité des enzymes intracellulaires et des enzymes kinins a été examinée dans le liquide pris des malades atteints de polyarthrite rhumatolde et de maladies connexes.

(2) Malgré que la moyenne des activités des enzymes intracellulaires variait d'après la maladie, celle des kinins ne variait pas. Cependant l'évaluation des activités des enzymes du liquide synovial ne constituerait pas une aide diagnostique sûre à cause d'un chevauchement considérable de valeurs individuelles chez les malades atteints de maladies différentes.

(3) Le liquide synovial contenant des cellules mais pas le liquide acellulaire de toutes les maladies des articulations y compris l'ostéoarthrose contenait la phosphatase acide, la $\beta$-glucuronidase et la déhydrogenase lactique, et l'activité de ces substances était plus élevée que celle du plasma correspondant. D'un autre côté les enzymes kinins étaient présents dans à peu près la même concentration dans le liquide centrifugé ou non-centrifugé, et cette concentration était plus basse que celle du plasma.

(4) Dans les articulations des malades atteints de polyarthrite rhumatoïde "classique" et de psoriasis, l'activité des enzymes intracellulaires était plus élevée dans le liquide synovial acellulaire que dans le plasma. Cependant non seulement les activités des enzymes lysosomiques étaient augmentées mais aussi celles d'autres enzymes intracellulaires. Cela indique une altération de la perméabilité de toute la cellule ou la mort de la cellule plutôt qu'une altération spécifique de la membrane lysosomique.
Enzimas intracelulares y enzimas kinin en el liquido sinovial en enfermedades articulares Origen y relación con la clase de enfermedad

\section{SUMARIO}

(1) Se ha examinado la actividad de enzimas intracelulares y de enzimas del sistema kinin en liquido sinovial obtenido de pacientes con poliartritis reumatoide y enfermedades asociades.

(2) $\mathrm{Si}$ bien las actividades medias de las enzimas intracelulares variaban con la enfermedad, aquellas de las enzimas kinin no variaban. Sin embargo, la medida de las actividades enzimáticas en el liquido sinovial no constituirá una base segura para el diagnóstico, a causa de la considerable superposición de valores individuales en pacientes con diferentes enfermedades.

(3) Se descubrió que el fluido sinovial que contentía células, pero no aquél libre de células, de todas las enfermedades articulares, entre ellas la osteoartrosis, tenía una actividad fosfatasa ácida, glucuronidasa $\beta$ y dehidrogenasa láctea significativamente mayor que las correspondientes actividades del plasma. Por otro lado, enzimas del sistema kinin estaban presentes en el liquido sinovial centrifugado y no centrifugado en aproximadamente la misma concentración, que era menor que los niveles del plasma.

(4) En las articulaciones de pacientes con poliartritis reumatoide "clásica" y con psoriasis, la actividad de las enzimas intracelulares era mayor en el fluido sinovial sin células que en el plasma. Sin embargo, no sólo aumentaron las actividades de lis enzimas lisosomales, sino también las de otras enzimas intracelulares. Esto indica una alteración en la permeabilidad de toda la célula o muerte de la célula, más que alteración específica alguna de la membrana lisosomal. 
(5) Malgré que la boulette obtenue après la centrifugation du liquide synovial contienne de hautes concentrations d'enzymes intracellulaires, elle contenait seulement de petites quantités d'enzymes kinins. De plus, le pH optimum et la sensibilité aux inhibiteurs des kininases et des enzymes formant des kinins dans le liquide synovial ressemblent à ceux des enzymes kinins dans le plasma et non à ceux des enzymes kinins présents dans les leucocytes polymorphonucléaires.

(6) Il a été conclu que les kininases et ceux formant les enzymes kinins dans le liquide synovial sont dérivés principalement du plasma et non des leucocytes envahissants.
(5) Si bien el gránulo obtenido después de la centrifugación del liquido sinovial contenía altas concentraciones de enzimas intracelulares, acusaba tan solo pequeñas cantidades de enzimas kinin. Además, el pH óptimo y la sensibilidad a los inhibidores de las enzimas que forman kinin y kininasa en el fluido sinovial se parecen a los de las enzimas kinin en el plasma y no a los que se relacionan con enzimas kinin presentes en leucocitos polimorfonucleares.

(6) Se llega a la conclusión de que las enzimas que forman kinin y kininasa en el fluido sinovial se derivan principalmente del plasma y no de leucocitos invasores. 